\title{
Erratum to: Bridging the Gap: Conceptual and Empirical Dimensions of Child Wellbeing in Rural Mexico
}

\author{
Laura J. Valadez Martinez
}

Published online: 23 March 2013

(C) Springer Science+Business Media Dordrecht 2013

\section{Erratum to: Soc Indic Res \\ DOI 10.1007/s11205-013-0289-8}

The Acknowledgments should read:

Research has been conducted with funding from CONACYT and data from Oportunidades. Portions of this paper are drawn from Valadez (2010). Eternal gratitude to Robert Walker and Mark Tomlinson for their permanent support and fruitful discussions. Special thanks to the anonymous reviewers whose attention to detail and comments have enriched this paper. Content and veracity remain the sole responsibility of the author.

The online version of the original article can be found under doi:10.1007/s11205-013-0289-8.

L. J. Valadez Martinez ( $₫)$

University of Oxford, Oxford, UK

e-mail: laura.valadezmartinez@oxon.org; laura.valadez@sant.ox.ac.uk 